\title{
Reception Analysis of Beginner Voter toward the Political Party Advertising of the Winning in the Election 2014
}

\author{
Reny Triwardani and Ida Wiendijarti
}

\begin{abstract}
Beginner voters are part of groups that have a right to vote in elections. They need political reference associated with the introduction of legislative candidates or political parties. Number of beginner voters in polls 2014 predicted to reach 40 percent of the overall number of voters. Political advertising spending on elections 2014 in the campaign time was very large. For beginner voters, political advertising plays an important role as a socialization media for the introduction of a political party as well as legislative candidates in the election. Political ad could be one of political references for them. The study aims to develop political advertising as socialization media for the beginner voters so it expected to increase political participation of beginner voters. This research is a qualitative research, with reception analysis methods. Data collection technique is by in depth interview and focus group discussion. The result showed that not all the audiences can understand completely the message of ads. Based on the televisual theory of Stuart Hall that the audience analysis divided in three positions recitation; predominant hegemonic, negotiations and the opposition. This research has theoretical implications for understanding political party ad(s) and election in Indonesia for beginner voters.
\end{abstract}

Index Terms-Political ads, beginner voter, reception analysis, media socialization.

\section{INTRODUCTION}

2014 is the year of politics in Indonesia. Beginner voters would need information about the election, political parties and legislative candidates before using the right to vote. According to Law No. 8 of 2012 article 19 paragraph 1 explaining that beginner voters are citizens who on polling day fulfilled aged 17 years or more or have been married have the right to choose [1]. Election Commission as election organizers noted that the number of registered voters on the 2014 election reaches 187852992 people with beginner voter prediction 40 percent of the total number voter [2]. Political advertising can be a socialization media on elections and political parties, especially during the campaign. The use of political advertising within political activity is commonly practiced in Indonesia.

For that reason, political ads can be understood as the most persuasive political communication. Political advertising is also known as a political marketing activities. This strategy is delivered to the voter to explain the positioning of political parties and candidates on the electoral market in the interest

Manuscript received September 9, 2015; revised Novermber 5, 2015. This work was supported in part by the Directorate General of Higher Education, Ministry of Education and Culture of Republic of Indonesia.

The authors are with the Faculty of Social and Political Sciences, Universitas Pembangunan Nasional Veteran Yogyakarta, Indonesia (email: reny.triwardani@gmail.com, idawiendijarti@yahoo.co.id). of achieving the goal of political communication. Political marketing implies the usage of marketing tools, techniques and methods in political process. As an activity and method, it reflects the penetration of the political space by marketing. Maarek (1995) appears to equate a company's consumer products with a political party's political communications. Such a parallel cannot be drawn, as a party's "product" does not consists of its political communications but of: a) its ideological platform and its set of policy proposals, b) the party leader, the candidates and party officials and c) party members in general [3].

Political ads play an important role in determining the political direction voter and the political ads on television have been spending the largest portion compared to other media. AC Nielsen data mentions that the growth of advertising spent reaching 2.04 trillion and television has became a prima donna for political parties to place ads in 2014 election (Selasar Economics, 2014) [4]. During the campaign in the legislative elections, political advertising spending on television reached 340 billions that was calculated starting on 16 March to 5 April 2014 [5] (see Tabl e I).

TABLE I: POliticAL PARTY ADVERTISING SPENDING 2014

\begin{tabular}{|l|l|l|}
\hline No & Political party & $\begin{array}{l}\text { Advertising spending } \\
\text { (Rupiah) }\end{array}$ \\
\hline 1 & Hanura & 70,5 Billion \\
\hline 2 & Demokrat & 56,8 Billion \\
\hline 3 & PAN & 43,8 Billion \\
\hline 4 & Golkar & 39,88 Billion \\
\hline 5 & PDIP & 33,58 Billion \\
\hline 6 & Nasdem & 33,28 Billion \\
\hline 7 & Gerindra & 26,49 Billion \\
\hline 8 & PKB & 20,68 Billion \\
\hline 9 & PPP & 9,69 Billion \\
\hline 10 & PKS & 4,93 Billion \\
\hline 11 & PKPI & 3,17 Billion \\
\hline 12 & PBB & 400 Million \\
\hline
\end{tabular}

Source: Sigi Kaca Pariwara, 2014 in Kompas.com

Political advertising on television has advantages since it becomes the most extensive coverage area up to $90 \%$ in Indonesia. According to M. Qodari, chairman of the Indo Barometer, the direct election system in 2014 make the political parties and politician should socialize the voters to choose them, especially party with a limited network. Advertisement on television becomes effective for political parties and politicians because they will be soon well-known and popular [6]. Currently, political advertising are being more used to build brand awareness, individual awareness, and awareness party.

This study aims to determine the voters experience as active audience that involved in the process of exchange 
messages and interpreting the meaning of a political party advertising that has won in 2014 election, which is aired by television. Construction of meaning displayed by political party through television ads can be interpreted differently by voters as an active audience. According to Hall (1980), the relationship between encoding and decoding are not completely symmetrical (see Fig. 1). Stuart Hall's "Encoding-Decoding" model of communication essentially states that meaning is encoded by the sender and decoded by the receiver and that these encoded meanings may be decoded to mean something else. That is to mean, the senders encode meaning in their messages according to their ideals and views and the messages are decoded by the receivers according to their own ideals and views, which may lead to miscommunication or something very different from what the sender intended to the receiver understanding. (Hall 1993: 510).

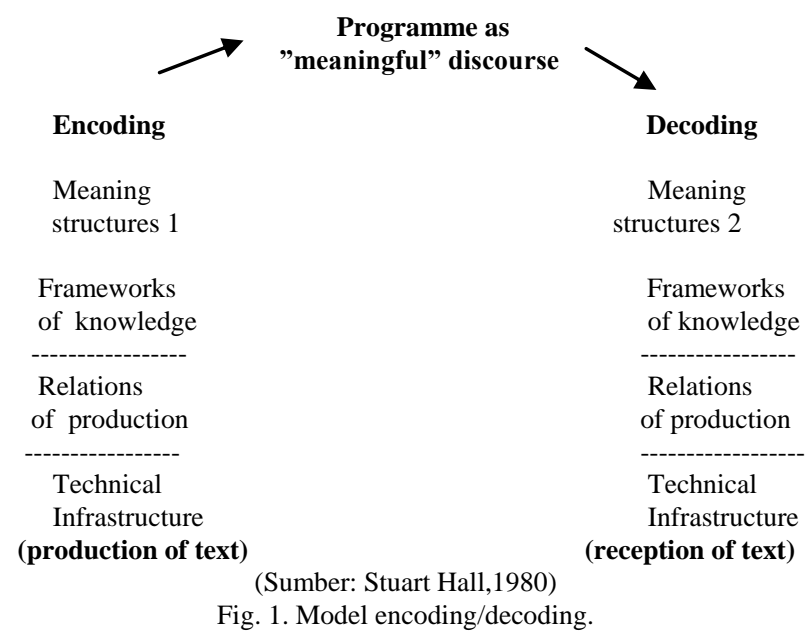

The idea is that individual interpret media texts in different ways. It demonstrates that even though one message is sent out, that not one understanding is received. Thus, according to Hall, media texts are polysemic and can be read in a number of ways. Hall says that there are three kinds of different positions audience take in order to decode the meanings within cultural texts, particularly televisual discourses. They are the dominant-hegemonic position, the negotiated position and the oppositional position. (Hall 1993:513) [7].

\section{RESEARCH METHOD}

The method used in the research was reception analysis. David Morley (1980) study of Nationwide was an early example of the encoding/decoding approach which is being utilised to investigate audience reception of media texts. Reception analysis has intensified our interest in the ways in which people actively and creatively make their own meanings and create their own culture, rather than passively absorb pregiven meanings imposed upon them (Ang, 1996:114) [8].

Data collection was conducted by Focus Group Discussions (FGD) to get depth. Focus group discussion is a systematic effort to collect data and some information from informants with three key words, namely: chat, group instead of an individual and not value-free or focused (Irwanto, 2006: 1) [9]. This technique facilitates researchers to find out the reason, the motivation, the argument or the basis of one person's opinion. People tend to be more comfortable discussing a topic as part of a group. Interaction between informants in discussing a topic becomes interesting observations of researchers.

Though this research does not focus on the media text, encoding processes has been done by viewing the content of political advertising as a preferred reading that produced. Political party ad content leads to a political commodity which is usually called 4Ps, namely, policy, person, party and presentation. Political advertising that is intended in this study is advertising political parties of the winning party in 2014 election, specifically PDI-P Party, Golkar Party and Gerindra Party.

At the stage of decoding, we focused on the reception analysis of beginner voters towards political party advertising of the winning in the 2014 election. Beginner voters are an active producer of meaning that interpret the meaning of content of political advertising freely. Criteria informants in this study were beginner voter who had seen advertisements of political parties of the winning in 2014 election. It is required that the informant has tied to the media texts, in order to know how the voters interpret the political parties ad on television, whether they accept or vice versa and have the position as the reading audience. Informants totaled 23 voters are divided into four group discussions. The distribution of electoral districts of informants were in Yogyakarta.

\section{RESULT AND ANALYSIS}

\section{A. The Reality of Political Party on Television Ads}

The three parties which have won in 2014 elections are PDI-P, Golkar Party and Gerindra. Golkar Party is the party with the greatest political ads spending. Political advertising on television aimed to carry out the function of advertising have informative function, the persuasive function, and reminder function. Reality of political parties shown on television commercial breaks represent preferred reading for voters.

Firstly, PDI-P ads of Indonesia Hebat version displays the images of yellow rice cone served with side dishes typical Slametan tradition. Slametan tradition is an event of thanksgiving that usually done by Javanese community in Indonesia. Then, there is a narrative that sounds "Tanpa kita sadari begitu banyak yang kita miliki namun sedikit yang kita kuasai". In the picture yellow rice cone, there are flags of other countries which are placed just above the side dishes. The flag image describes that the chicken are imported from Malaysia, potatoes from Australia, beef from American, soybean from Malaysia and maize from India (see Fig. 1).

This clearly indicates that food import practices are needed to fulfill the side dishes on rice cone. It presents an irony. The yellow rice cone symbolizes Thanksgiving moment in Javanese culture. On the other hand, side dishes that served with the rice cone are came from food import. PDI-P ads implies populist symbol that represented with the iconic 
message on the rice cone. It describes the most Indonesia citizen's basic needs for food. The cone refers to the shape of mountain, which became the ancestor worship place where believed as the dwelling place of the Creator's spirit. Therefore, the yellow color represents prosperity. This ad implies that PDI-P has the party program to achieve food self-sufficiency. The program goal is to achieve food sovereignty in order to create well-being.

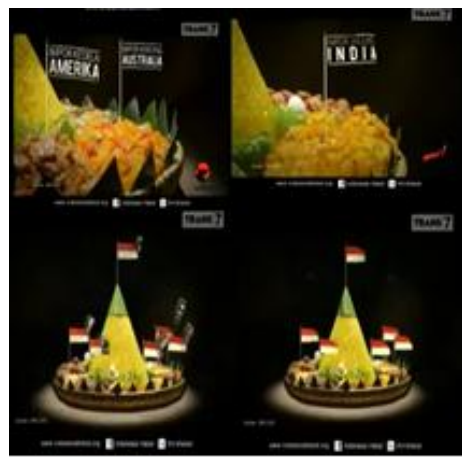

Fig. 1. Food import practices.

Another meaning of this ads represents PDIP party deterrmination which is confirmed by Puan Maharani, Chief Executive of PDIP who states that "Kita tanam yang kita makan, kita beli dari petani kita sendiri". Hands Clenched with a firm voice message symbolizes the determination of the party to embody the slogan "Indonesia Hebat" for Indonesia (see Fig. 2).

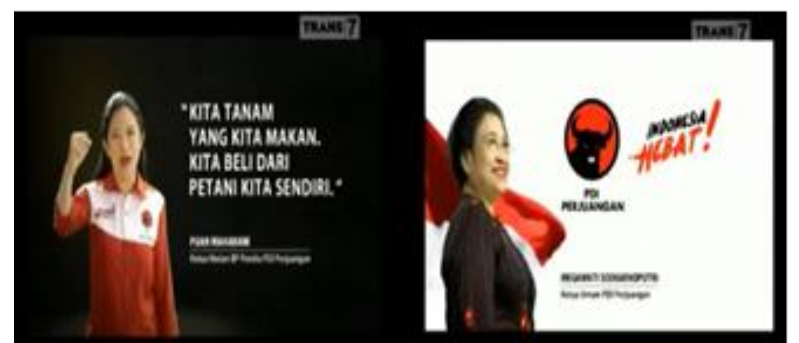

Fig. 2. Puan Maharani and Megawati Soekarno Putri.

At the end of the ads, the figure of the PDI-P's chairman, Megawati Soekarnoputri, appeared with a concluding statement "Indonesia Hebat", and gave an anchor message. She is the central icon in this ads. Megawati and Puan Maharani as the leader's party are strong people who were behind the PDIP. Both of them have a kinship with the first Indonesia president, namely Ir.Soekarno. The appearance of these two figures implies that party is led by a fighter for the peoples and the nation interests. The background of Indonesia's flag symbolizes nationalism spirit. The black and white color with dominance red color as the party's logo confirms that PDI-P serves national interests above the political party or group interests with determination and braveness.

Secondly, Golkar party ads emphasize the citizen testimonies as the ads appeal. This party tries to seize the voter choice with the persuasive message from the citizen rather than from the party's leader itself. The ad theme is a comparison of the government period. Golkar Party has become the ruling class for 32 years. It implies that the party has a track record for governing. The comparison between
Golkar party regime with another parties as ruling class in the government become main issue in this ads. For the beginning of ads, by featuring a middle-aged person, illustrate that these people live in the different government era. Then, that person gives testimonies stressed that how successful Golkar Party leads the government for five years period. The testifier tries to raise up the memories of the Soeharto era, particularly the development programs that succeed (see Fig. 3)

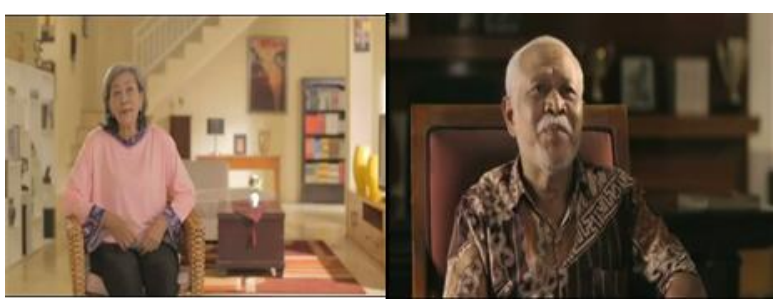

Fig. 3. middle-aged person as testifier.

It starts from the question that is mentioned about how to live in the different era and then continued with the closing question about choosing the better government period. Each testifier noted that Soeharto regime was the best time to live prosperous. Interestingly, the emergence of the figure of Soeharto became the central icon on ads and none of the party leaders were appeared. This iconic message represents the success evidence of the Golkar party during their governing period over 5 periods ago. It also implies that this party has a great figure. The party program such as sustainable development and achievement of food self-sufficiency sought to remind that the people will live in prosperity under the Golkar party leadership (see Fig. 4).

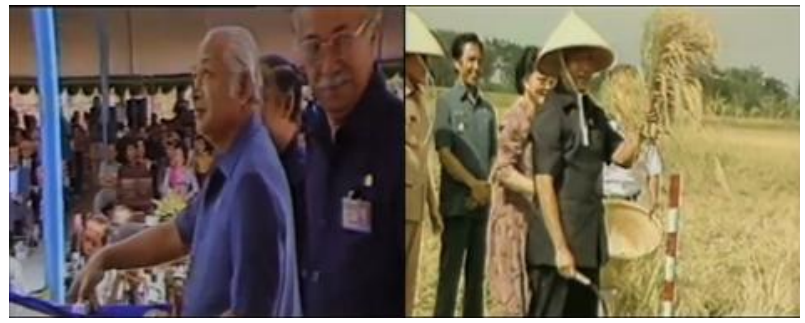

Fig. 4. Soeharto image.

At the end of ads testimony, a closing statement which sounds "Suara rakyat benar, zaman enak zaman Golkar", confirms that this party is a party that articulate the people aspiration as stated on the party slogan," Suara Golkar Suara Rakyat". This party had color domination of yellow with the banyan tree on the party logo. It symbolizes prosperity for the yellow color and shelter for the banyan tree.

Lastly, Gerindra is the third winner in 2014 election. This party ads has meaningful discourse. The party logo, an eagle's head symbolizes nationalism due to the eagle is an attribute of the state of Indonesia. Red and gold color dominance confirms the spirit for reaching national prosperity. This party ad starts with description of society in Indonesia that is represented by the image of paddy fields and skyscraper buildings. It implies the type of society in Indonesia namely rural and urban communities (see Fig. 5).

Narrative message that encoded on this ad is the power to change. This is the power that drive the party to reach the action program, raising Indonesia to be Asia's tiger, economy populist, people's progress, eradication of 
corruption, strong governance, and education quality. All the agenda could be reached out by people themselves. The power of change is the keyword for bringing up Indonesia.

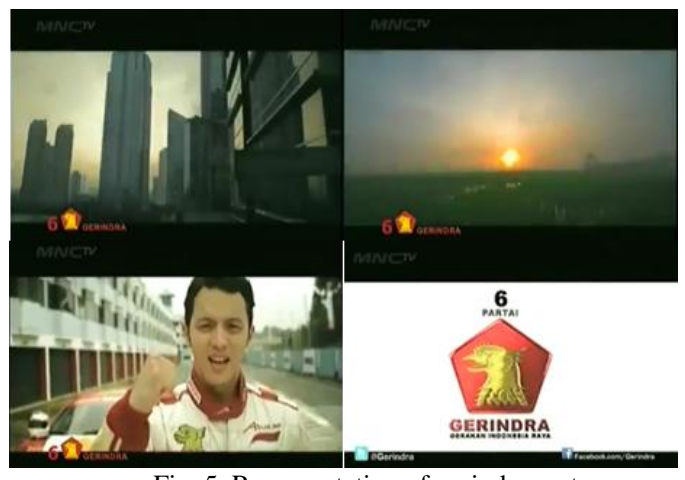

Fig. 5. Representation of gerindra party.

Prabowo Subianto, the chairman of the party, will be the future leader come from this party. His performance in building project location with the workers, then getting a dialogue together with particular groups, shaking his hands, and chatting with the residents tries to capture his competence and ability as a great leader. This scene is part of personal branding of Prabowo Subianto. He will be president candidate in the Presidential election (see Fig. 6).

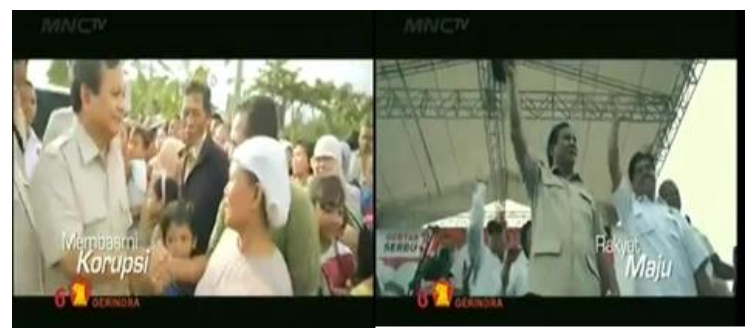

Fig. 6. Brand image of prabowo Subianto.

Overall, political party ad applies the function of advertising. Each political party ad of the winning the election in 2014 offers preferred reading that emphasized on the political party commodities which called by 4P (Policy, Person, Party, Presentation) of political marketing activities (see Table II).

TABLE II: POLITICAL PARTY AD CONTENTS

\begin{tabular}{|l|l|l|l|l|}
\hline $\begin{array}{l}\text { Political } \\
\text { party Ads } \\
\text { content }\end{array}$ & PDIP PARTY & $\begin{array}{l}\text { GOLKAR } \\
\text { PARTY }\end{array}$ & $\begin{array}{l}\text { GERINDR } \\
\text { A PARTY }\end{array}$ & $\begin{array}{l}\text { PREFERRED } \\
\text { READING }\end{array}$ \\
\hline POLICY & $\begin{array}{l}\text { Food import } \\
\text { practice issue } \\
\text { Self } \\
\text { sufficienty } \\
\text { policy }\end{array}$ & $\begin{array}{l}\text { Sustainable } \\
\text { Development } \\
\text { program }\end{array}$ & $\begin{array}{l}\text { Power of } \\
\text { change } \\
\text { Action } \\
\text { program } \\
\text { parties }\end{array}$ & $\begin{array}{l}\text { Apply the } \\
\text { function of } \\
\text { advertising }\end{array}$ \\
\hline PERSON & $\begin{array}{l}\text { Megawati } \\
\text { Soekarnoputri } \\
\text { Puan } \\
\text { Maharani }\end{array}$ & $\begin{array}{l}\text { Middle aged } \\
\text { person } \\
\text { Soeharto }\end{array}$ & $\begin{array}{l}\text { Prabowo } \\
\text { Subianto } \\
\text { Moreno } \\
\text { Soeprapto }\end{array}$ & $\begin{array}{l}\text { Public figure } \\
\text { endorser }\end{array}$ \\
\hline $\begin{array}{l}\text { PARTICAL } \\
\text { PARTY logo, } \\
\text { Number of }\end{array}$ & $\begin{array}{l}\text { Participation } \\
\text { Number of logo, } \\
\text { participation }\end{array}$ & $\begin{array}{l}\text { Party logo, } \\
\text { Number of } \\
\text { participation }\end{array}$ & $\begin{array}{l}\text { Party's } \\
\text { attribute and } \\
\text { tagline } \\
\text { recognized } \\
\text { and popular }\end{array}$ \\
\hline PRESENTA \\
TION & $\begin{array}{l}\text { Icon white } \\
\text { muzzle a hulls head, } \\
\text { the Indonesian } \\
\text { flag } \\
\text { Dominance of } \\
\text { red, white, and } \\
\text { black }\end{array}$ & $\begin{array}{l}\text { Icon Banyan } \\
\text { tree and } \\
\text { Dominance of }\end{array}$ & $\begin{array}{l}\text { yellow } \\
\text { Icon eagle's } \\
\text { Dominance } \\
\text { of red and } \\
\text { gold }\end{array}$ & $\begin{array}{l}\text { Brand image } \\
\text { political party }\end{array}$ \\
\hline
\end{tabular}

Reality of political parties in television advertising showed that the ad's persuasive function attracts the attention of beginner voters. Political party builds brand image with the party programs as the party vision mision implementation. PDIP uses the national issue about imported food to sounds its food policy. Golkar party emphasizes their success in the past with the Soeharto government era, and Gerindra emphasizes the power to change for raising Indonesia as Tiger Asia. On the appeal of ads, the Golkar party count heavily on the testimony of citizen while PDIP and Gerindra rely on the storytelling approach. Attributes of political parties also appear to remind the beginner voter in order to vote the political party. Each political party performs typical party logo's color to give strong message's impression. Creatively, political parties also use the endorser in the ads such as political party member or public figure.

\section{B. The Reading Position of Beginner Voter toward the Political Party Ads}

Beginner voters as informants in this study divided into focus group discussion. Each discussion group do the reception toward the political party advertising. Most informants are students and some of them are already working. As beginner voters, informants realize that the political information is needed as a political reference before voting time. Each group consisted of 5-7 people who come from different constituencies. Each informant in the group interprets the same political party advertising, but the position of readings from the message content can be different. There are three position of readings such as dominant reading, negotiated reading, and oppositional reading (Hall, 1980) (See Table III).

TABLE III: RECEPTION POSITION OF THE BEGINNER VOTER TOWARD THE POLITICAL PARTY ADVERTISING

\begin{tabular}{|l|l|l|l|}
\hline \multirow{2}{*}{$\begin{array}{l}\text { Beginner voter } \\
\text { group }\end{array}$} & \multicolumn{3}{|c|}{ Preffered Meaning } \\
\cline { 2 - 4 } $\begin{array}{l}1^{\text {st }} \text { Group } \\
\text { (Ghea, Desta, Putri, } \\
\text { Otto,Auk, Multan, } \\
\text { Rea) }\end{array}$ & Negotiated & Oppositional & Negotiated \\
\hline $\begin{array}{l}2^{\text {nd }} \text { Group } \\
\text { (Kristi, Arina, } \\
\text { Gilang, Lita, Debby, } \\
\text { Shanti) }\end{array}$ & Negotiated & Oppositional & Oppositional \\
\hline $\begin{array}{l}3^{\text {rd }} \text { Group } \\
\text { (Reza, Herlambang, } \\
\text { Adeline, } \\
\text { Novi,Wenang) }\end{array}$ & Negotiated & Negotiated & Negotiated \\
\hline $\begin{array}{l}4^{\text {th }} \text { Group } \\
\text { (Nanda, Fahmi, } \\
\text { Andika, Rofiq, } \\
\text { Amalia) }\end{array}$ & Dominant & Negotiated & Dominant \\
\hline
\end{tabular}

To begin with, it is important to know that the voters exposured by a political ads and then recognized them as the way of political party socialization from a political party. This insights may lead to the interpretation of political ad readings.

The first group discussion consists of six students that came from Bantul, Sleman, and Kota Yogyakarta. All of them have a chance to vote for the first time in the election 2014. They seem eager to participate in the election. They are looking for information on political parties which contesting 
the election from various media. They read the news, articles, opinion columns, and expert reviews about the election issues. Interestingly, they also find out at You Tube. When they saw the political party ad that aired on television, they discuss vigorously about the meaning of political advertising that they have watched.

During the group discussion, all informants agreed that the political ads are imaging media for political parties. Messages which emerged strongly in the ad-laden charged mere political promises. In this sense, they often saw PDI-P, Golkar and Gerindra ads on television. They sometimes also see it from You Tube channel. For them, political party advertisement provide general information about the political parties.

They understand that the PDIP party ads are trying to resolve the food problem in Indonesia by stopping imported food and strengthening food self-sufficiency as a matter of fact which they are not sure whether it could be really happen if PDIP is chosen as the winner in the election. Meanwhile, within the Golkar ad, they totally can not capture what is Golkar party intention with the message mentioned "Zaman enak zaman Golkar" (Good times, Golkar times). A testifier in the ad only gives the impression that the leadership period not represent what are the ad message meanings. In the third ad, Gerindra party used animal metaphor to describe the message intent in advertising. Gerindra takes a crack to develop various sectors of life with a change movement. To put it more generally, first groups tend to negotiate the meaning of PDIP and Gerindra ad, but they are strongly opt for oppositional readings on Golkar party's advertising which didn't have a clear intention at all in demonstrating the comparison period regarding to the party's vision mission or even its programs.

Next, in the second group discussion, all informants are students from various campus as well. They negotiate the meaning of PDIP advertisement in the same way with the first group. They can capture the ad messages meaning clearly enough. PDIP party leads them to know how the Indonesian too dependent with food import.It seems like Indonesia is still far away from the freedom meaning itself. However, they also very strongly identify it as party imaging. Different from the first group, they choose oppositional readings of the Golkar and Gerindra party's messages ads. The ads duration were too long to make them understand the messages point. The informants need extra time to catch the idea or some meanings in it. Golkar party gives them the past memories only and the Gerindra party focuses on image branding of the president candidate.

For instance, the third group discussion consists of five persons. In this group, most of them are students in advertising major and young workers. They agree that the political ad purposed to socialize the political party existence. Political parties create their messages as attractive as possible to persuade the voters. To observed the ads, all informants in this group have negotiated all the ads that they are watched. Their knowledge as an advertising student provides a reference to recognize the significancy of political advertising. PDIP very clearly shows the hero syndrome in its advertising messages. In contrary, Golkar party that attract the audience with demonstrating the past regime dominance that may not be understood by beginner voters like them. In the same way, Gerindra party attempted to convince voters to involve in the change movement. An informant who has worked explained that Gerindra party has a huge base in her residence area so that this party ad is so popular and familiar in the community surroundings.

Lastly, the fourth group discussion, all of the informants are students. During the group discussion, they show the impression that political ad contents are acceptable for them. An informant who is a farmer child, gave an opinion straightly that he will choose the pro farmer party. The others also expressed the same opinion. They accept PDIP's ad and the Gerindra due to the story telling power to deliver the ad messages and taken for granted in its meanings. For the Golkar party ad, they prefer to negotiate the ad meanings. The idea to compare the government led by Golkar party or another party was not only a great idea but also have creative story telling. They think that the ad gives the review of each government clearly enough.

\section{CONCLUSION}

Political advertising serves as a medium of political socialization. Ad also persuades voters to vote for a particular political party. In the direct election system, political parties advertise themselves to attract the attention of voters as the target audience. The substance of advertising theme emphasizes the vision, mission and political parties programs, which are visualized with images, sound and narration. Political party ads create specific structures of ideological significance. Each winning political party ad in the election seeks to build the image as a pro-people party.

The identity of the party such as a logo, party name, and the serial number of the election appears in the ad to remind voters of the party's existence. The party's slogan or tagline as supporting appeal has strengthen the ad message. Voters are expected to be more easily recognize a political party with an eye-catching display and full of meaningful ads. Political party also uses an iconic figure in the party. Figure of the chairman as a brand image confirms the positioning of the party chairman leadership. Communication strategy that is built become the closeness or homophily and empathy in force delivery of advertising messages.

At the stage of reception analysis, beginner voter is not only as a consumer of the political advertising content, but also as a producer of meaning. Their reading against political party ad is not necessarily in accordance with the intention desired by the producer of the text. Most informants perform a simple negotiation mechanism. Position reading of the voters towards political advertising tends to conduct negotiated and oppositional rather than dominant. The difference factors of the beginner voters reception due to the differences in socio-cultural background, knowledge structure, surrounding family and peer group circle. Lastly, the political ad is not the only source of political information possessed by voters. Political references voters were also obtained from other sources such as news, direct campaign, or other media. 


\section{ACKNOWLEDGMENT}

This work was fully supported by Universitas Pembangunan Nasional Veteran Yogyakarta, Indonesia. Thank you to the Dean and our Rector of UPN Veteran Yogyakarta who have motivated us to finish this research. Special thanks to beginner voters who have participated as key informants in the focus group discussion of this research.

\section{REFERENCES}

[1] Law No. 8 In 2012 About General Election of DPR, DPD and DPRD in Article 19 paragraph 1.

[2] Pemilih Pilpres 2014 bertambah 2,4 Juta, 2014.

[3] S. V. Menon. (December 2008). Political marketing: A conceptual framework. Munich Personal RePEc Archive. [Online]. Available: http://mpra.ub.uni-muenchen.de/12547/

[4] Awal Tahun 2014, Iklan Politik Dominasi Media, Selasar Ekonomi, May 9, 2014

[5] Belanja Iklan Parpol Selama Kampanye Pileg Capai 340 Milliar, April $11,2014$.

[6] Sering Iklan Politik Belum Tentu Menang, August 23, 2008

[7] S. Hall, "Encoding/decoding," The Cultural Studies Reader, London, NY: Routledge, pp. 507-517, 1993
[8] A. Ien, Living Room Wars: Rethinking Media Audience for a Postmodern World, London: Routledge, p. 114, 1996.

[9] Irawanto, Focused Group Discussion, Jakarta: Universitas Katolik Atmajaya Jakarta, p. 1, 2006.
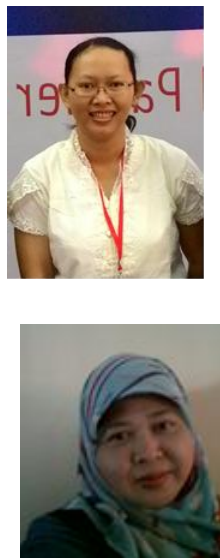

Reny Triwardani is a lecturer in the Department of Communication Science, Faculty of Social and Political Sciences, Universitas Pembangunan Nasional Veteran Yogyakarta, Indonesia. She received her MA from Gadjah Mada University, Yogyakarta in 2011. She teaches the bachelor of communication. She specializes in local culture and cultural studies, audience and media studies. She lives in Yogyakarta.

Social and Political Sciences, Universitas Pembangunan Veteran Yogyakarta, Indonesia. Ms.Wiendijarti has research interest in broadcasting, and psycology communication. 